\title{
Fear of childbirth in time of the new coronavirus pandemic
}

\author{
O medo do parto em tempo de pandemia do novo coronavírus \\ El temor al parto en tiempos de pandemia del nuevo coronavirus
}

\section{Sandra Patrícia Arantes do Souto' ORCID: 0000-0003-2206-7540}

Rosemeire Sartori de Albuquerque" ORCID: 0000-0001-6915-4508

Ana Paula Prata"l' ORCID: 0000-0001-7552-9716

'Universidade Católica Portuguesa, Instituto de Ciências da Saúde. Porto, Portugal. "Universidade de São Paulo. São Paulo, São Paulo, Brazil.

III Escola Superior de Enfermagem do Porto, Centro de Investigação em Tecnologia e Serviços de Saúde. Porto, Portugal.

How to cite this article: Souto SA, Albuquerque RS, Prata AP. Fear of childbirth in time of the new coronavirus pandemic. Rev Bras Enferm. 2020;73(Suppl 2):e20200551. doi: http://dx.doi.org/10.1590/0034-7167-2020-055

\section{Corresponding author:}

Sandra Patrícia Arantes do Souto E-mail: patriciaarantessouto@gmail.com

EDITOR IN CHIEF: Dulce Barbosa ASSOCIATE EDITOR: Ana Fátima Fernandes

Submission: 05-25-2020 Approval: 08-22-2020

\begin{abstract}
Objective: Reflect on how the new coronavirus pandemic triggered or accentuated the fear of childbirth in pregnant women and affected childbirth care practices. Methods: Reflective analysis of women's pregnancy and childbirth experiences during the current pandemic, supported by the latest scientific evidence and recommendations on the topic. Results: Pregnancy and childbirth are life-changing events for women, but during the new coronavirus pandemic, fear and uncertainty have taken on an unprecedented dimension in the negative way that many pregnant women have anticipated and experienced childbirth. Final considerations: The current period has accentuated a chronic problem: a paternalistic system of health institutions in the approach to childbirth, dense with additional levels of fear in pregnant women. In this context, addressing the fear of childbirth means not giving up the promotion of safe and positive birth experiences for women.
\end{abstract}

Descriptors: Pregnant Women; Fear; Delivery; Coronavirus Infections; Pandemics.

\section{RESUMO}

Objetivo: Refletir acerca da forma como a pandemia do novo coronavírus desencadeou ou acentuou o medo do parto nas gestantes e afetou as práticas de assistência ao parto. Métodos: Análise reflexiva sobre as experiências de gravidez e parto de mulheres, durante a atual pandemia, sob o suporte das mais recentes evidências científicas e recomendações sobre o tema. Resultados: A gravidez e o parto são acontecimentos transformadores na vida das mulheres, mas, no decorrer da pandemia do novo coronavírus, o medo e a incerteza ganharam uma dimensão sem precedentes na forma negativa como muitas gestantes têm antecipado e experienciado o parto. Considerações finais: $O$ período atual acentuou um problema crónico: um sistema paternalista das instituições de saúde na abordagem ao parto, adensado por níveis adicionais de medo nas gestantes. Nesse contexto, abordar o medo do parto significa não abdicar da promoção de experiências seguras e positivas de parto para as mulheres.

Descritores: Gestantes; Medo; Parto Obstétrico; Infecções por Coronavírus; Pandemias.

\section{RESUMEN}

Objetivo: Reflejar acerca de cómo la pandemia de COVID-19 desencadenó o acentuó el temor al parto en las embarazadas y afectó las prácticas de asistencia al parto. Métodos: Análisis reflexivo sobre las experiencias de embarazo y parto de mujeres, durante la actual pandemia, bajo el soporte de las más recientes evidencias científicas y recomendaciones sobre el tema. Resultados: El embarazo y el parto son acontecimientos transformadores en la vida de las mujeres, pero, en el curso del nuevo coronavirus, el temor y la incertidumbre ganaron una dimensión sin precedentes negativamente como muchas embarazadas han anticipado y experimentado el parto. Consideraciones finales: Actualmente acentuó un problema crónico: un sistema paternalista de las instituciones de salud en el abordaje al parto, adensado por niveles adicionales de temor en las embarazadas. Así, abordar el temor al parto significa no abdicar de la promoción de experiencias seguras y positivas del parto para las mujeres.

Descriptores: Embarazadas; Temor; Parto Obstétrico; Infecciones por Coronavirus; Pandemias. 


\section{INTRODUCTION}

On December 31, 2019, the disease of the new coronavirus (COVID-19), caused by the SARS-CoV-2 virus, was reported for the first time. The World Health Organization (WHO) declared, on January 30, 2020, that the outbreak of COVID-19 disease constitutes a Public Health Emergency of International Concern (PHEIC) - the highest level of alert in the Organization, as provided for in the International Health Regulations. The virulence and high transmission capacity of the SARS-CoV-2 virus surprised epidemiologists, infectious diseases, health professionals and policy makers, which led WHO, on March 11, 2020, to declare a state of pandemic. To date, COVID-19 affects 216 countries, areas or territories worldwide ${ }^{(1)}$. According to WHO data, a report of August 2, 2020 informs us that, so far, the world has recorded a total of $17,660,523$ cases and 680,894 deaths, with the Region of the Americas registering 9,476,763 confirmed cases and 359,180 deaths; and the European Region has 3,375,535 confirmed cases and 213,284 deaths $^{(2-3)}$. In the Region of the Americas, the United States leads the ranking in the number of total cases $(4,523,888)$ and deaths $(152,630)$, followed by Brazil with 2,662,485 cases and 92,475 deaths $^{(2)}$. In Portugal, on August 2, the number of confirmed cases is 51,310 and the number of deaths is $1,737^{(2)}$. The permanent update of epidemiological data shows how, for the first time, we are facing a pandemic that is happening in real time and in which there are no borders that dilute information.

Throughout the world, COVID-19 found health systems unprepared, with limited responsiveness, which led to a need to act collectively, urgently, and unprecedentedly in the history of the past hundred years. According to the adaptation phase, new challenges are posed to Public Health, Health Systems and Global Security daily, to be overcome with the help of reliable, impartial information based on the best available evidence.

According to information available to date ${ }^{(3-5)}$, the person-toperson transmission route of the new coronavirus (SARS-CoV-2) occurs through respiratory droplets (expelled during speech, coughing or sneezing) and also through direct contact with infected persons or indirectly through contaminated hands, objects or surfaces, similarly to the spread of other respiratory pathogens. With limited evidence regarding effective drugs or treatment strategies and no vaccines available, the current response to COVID-19 is based on efforts to slow the spread of the virus and reduce the number of deaths as much as possible. Thus, in addition to standard precautions, contact precautions, droplets and aerosols should be implemented by all health services. Based on this knowledge, fundamental procedures to prevent transmission have been highlighted, such as hand washing, respiratory etiquette and physical distance between people $\mathrm{e}^{(3-4)}$. However, the challenges we face with the new coronavirus pandemic are more like solving the Rubik's cube, fundamentally because we are dealing with a virus about which scientific knowledge, although with advances and at an unusual speed, is still reduced.

And in this chaotic state of the world, women continue to have children. Initially, pregnant women were not a risk factor for COVID-19, but they are currently included in this classification. Although their universe is inferior, compared to that of patients in general, it is important to highlight that they require special care, in order to preserve good obstetric practices, while protecting the mother-child binomial of COVID-19. Although there are many aspects that can be discussed, this article aims to reflect on how the pandemic of the new coronavirus affected the expectations of pregnant women, by triggering or accentuating the fear of childbirth, as well as childbirth care practices, based on in the most recent scientific references.

The results will be described in three categories. First category: approaching the new coronavirus pandemic as a source of fears for pregnant women; second category: reflection on the relationship between fear of childbirth in pregnant women and obstetric practices implemented in institutions throughout the pandemic; third category: discussion about the intervention of midwives in pregnant women with fear of childbirth in the pandemic era of COVID-19, with the presentation of a proposal for strategies that respond to the challenge of fear of childbirth.

In this categorization, there is a central axis established between the opinion and the arguments of the facts, highlighting the scientific support on the ways of transmission and prevention of infection by the new coronavirus, which led the official bodies to recommendations regarding the already established good obstetric practices, such as: companion(s) control during labor, delivery and postpartum; use of obstetric interventions; criteria for skin-to-skin contact, clamping of the umbilical cord and joint accommodation; care with breastfeeding; among others that, inevitably, were added to the set of feelings related to the fear and insecurity of pregnant women.

\section{METHODS}

The methodology is based on a reflective analysis on the fear of childbirth in pregnant women and on childbirth care practices, during the pandemic of the new coronavirus. The analysis will take as its starting point the experiences of women and midwives/ obstetricians from different health institutions, transmitted personally, or disseminated by the media (e.g. television reports) and social networks (e.g. testimonies personal experiences shared in groups on Facebook and Twitter), which will be discussed with scientific basis for recommendations on care in pregnancy, labor and delivery and postpartum, during the new coronavirus pandemic, and which have been published by national and international reference organizations until August 2, 2020.

\section{RESULTS}

\section{The new coronavirus pandemic: a source of fear for preg- nant women}

Pregnancy and childbirth are life-changing physiological events for women. Many of them face childbirth concerns, anxieties, and fears, although they express them in different ways. In recent decades, fear of childbirth has permeated the discourse of women and their families, health professionals and health policy makers. And it has been a field of interest for research due to its predictive factors and potentially negative repercussions on the health and well-being of women of reproductive age ${ }^{(6)}$.

As the SARS-CoV-2 virus continues to spread worldwide, prenatal management, fetal safety and the potential for vertical 
transmission are of significant interest and concern. The COVID-19 disease pandemic appears as a new source of fear among all pregnant women and families because it seems to accentuate: the meaning of the unknown and the unpredictability of childbirth; exposure to danger and lack of security; submission to the protocols of health institutions, with the cancellation of the possibility of personal choices; the feeling of loss of control during pregnancy and childbirth; and the uncertainties about the future. We live in a vulnerable world, and vulnerability is the center of fears and the struggle for expectations. Faced with a period of crisis, and facing a moment of life without return, we see pregnant women, their partners and families mourning some of their expectations, when they realized that they could not attend childbirth and parenting preparation sessions in person; that some of the consultations on the pregnancy surveillance plan would be cancelled or carried out through digital platforms; some face-to-face consultations would take place, but without the possibility of the pregnant woman having a person accompanying her; and that, after birth, they could not be reunited with family.

The last 30 years of research have shown us how difficult it is to define "fear of childbirth", and the current events have shown us how this concept can still be subject to further scrutiny, vulnerability, and mutability. With the COVID-19 crisis, the siege surrounding the concept of fear of childbirth seems to have deteriorated.

But the challenges of fear of childbirth do not stop there.

\section{Fear of childbirth and obstetric practices in the COVID-19} era: between scientific and ethical lapses

In clinical practice, there seems to be an association between fear of childbirth in women and fear: of obstetric interventions; loss of autonomy in decision making; the structural aspects of the obstetrics service; abandonment during labor and delivery; as well as mistreatment and violence by health professionals. These causes of fear of childbirth are part of a current discussion on obstetric practices and women's rights in pregnancy and childbirth.

In this context, what impact will the COVID-19 pandemic have on fear of childbirth and under what conditions will women be giving birth? In Portugal, Brazil, as well as in other countries in the world, midwifery services were weakened and needed to adapt under very challenging conditions. No less disturbing is the way health institutions have chosen to deal with the situation regarding childbirth care practices. In the name of the contingency plans for COVID-19, years of good obstetric practices were retreated, with regard to equal access to quality perinatal care and the protection of rights provided for by law and recommended by the most relevant organizations. Without logical arguments related to the prevention of infection transmission, the practices reviewed included: prohibition or control of the companion(s) during labor, delivery and postpartum; suspension of the presence of doulas; absolute restriction of visitors; recourse to unnecessary obstetric interventions; criteria for skin-to-skin contact, clamping of the umbilical cord and joint accommodation; and breastfeeding care.

In fact, the COVID-19 pandemic has raised an escalation of concerns due to the suspension of the woman's right to the companion(s) during labor, delivery and postpartum, to the performance of unnecessary obstetric interventions, such as inductions at 39 or 40 weeks of gestation and caesarean sections, without clinical indication. Situations are also reported in which skin-to-skin contact, rooming-in and breastfeeding were discouraged, in suspected or confirmed cases of women diagnosed with COVID-19, on the grounds of being potentially unsafe practices.

Pregnant women represent a unique population in health care and, in this context of a pandemic, effective responses will continue to depend on strategic plans that guarantee safe, equitable, compassionate, respectful and evidence-based care ${ }^{(5,7-8)}$. Since the beginning of the crisis, the interpretation of which strategies are associated with safe care is the cause of a strong debate among those who, on the one hand, consider that this situation has only shown how many obstetric services use practices that neglect scientific and ethical guidelines and, on the other hand, those who advocate restrictive practices under the argument of protection and prevention of preventable damage.

Since March 2020, there has been an exponential increase in publications in maternal and obstetric health. However, many doubts remain about how the new coronavirus behaves in pregnant women and new-borns. It is essential to understand that, in view of the numerous possibilities for research questions on the subject, the available studies are still scarce, were carried out on small samples and lack more robust research designs. So far, several international reference organizations have commented on guidance documents - in the meantime submitted to reviews - on care during pregnancy, labor, delivery and postpartum, in this COVID-19 era, such as the World Health Organization ${ }^{(5)}$, the Royal College of Obstetricians and Gynaecologists (RCOG), Royal College of Midwives, Royal College of Paediatrics and Child Health, Public Health England and Public Health Scotland ${ }^{(8)}$, the American College of Obstetricians and Gynecologists (ACOG) $)^{(9)}$ and the Centers for Disease Control and Prevention ${ }^{(10)}$, among others.

Based on the knowledge available to date, pregnant women may be at increased risk compared to COVID-19 and to nonpregnant women ${ }^{(3,8-10)}$, being considered a clinically vulnerable group $^{(8)}$. In addition, there may be a greater risk of adverse pregnancy outcomes among pregnant women with COVID-19. So far, the SARS-CoV-2 virus has not been detected in vaginal secretions, the placenta or amniotic fluid, but data are limited. It has been found in some breast milk samples, but the risk of transmission if swallowed is not evident ${ }^{(8-10)}$, so breastfeeding is recommended due to its known benefits ${ }^{(8)}$. Although, it is known that newborns can be infected with the virus after close contact with an infected person, and some newborns tested positive for the virus shortly after birth. However, it is not known whether the virus was transmitted before, during or shortly after birth; thus, vertical transmission remains in the investigation as a hypothesis. According to reliable sources, there is still no consistent data on the risks of COVID-19 for newborns ${ }^{(8-10)}$.

On March 18, $\mathrm{WHO}^{(5)}$ provided specific guidelines on the care to be taken during pregnancy, childbirth and postpartum due to the presence or suspicion of SARS-CoV-2 infection. In relation to childbirth, it states that any woman has the right to a safe and positive birth experience, which includes: being treated with respect and dignity; having a companion of your choice present during delivery; clear communication by the maternal health 
care team; appropriate pain relief strategies; mobility in labor, whenever possible; and choice of position for expulsion. In this publication, $\mathrm{WHO}^{(5)}$ advocates skin-to-skin contact and joint accommodation. It also establishes that women with suspected or confirmed COVID-19 can breastfeed and care for their newborns, ensuring measures of respiratory etiquette, hand washing and regular disinfection of surfaces. In case of worsening COVID-19 disease or other complications, the woman should be supported to provide her baby with breast milk in a possible, available, and acceptable way for them. Finally, $\mathrm{WHO}^{(5)}$ does not promote labor induction or caesarean section, without clinical indication.

On March 30, the Directorate of General Health (DGS)(11), in Portugal, issued a statement with guidelines for monitoring pregnancy and childbirth care for positive or suspected SARSCoV-2 pregnant women. DGS recommended that it be left to each health institution to apply some of the measures. In addition to considering that the recommendations were at odds with WHO directives, it seems that there was an error in the interpretation of the directive by some health institutions, when applying some of these measures to all women, regardless of whether they had a positive or negative result on the SARS-CoV-2 virus test. Later, on June 5, the DGS working group reformulated the guideline based on the evidence available to date and in collaboration with the College of Maternal and Obstetric Nursing of the Order of Nurses and the College of Specialty of Gynecology and Obstetrics of the Order Doctors ${ }^{(11)}$.

In Brazil, the Ministry of Health (MS) issued technical note no. 9- Recommendations for labor, delivery and the postpartum during the COVID-19 pandemic ${ }^{(12)}$, in order to provide recommendations for health professionals alongside current evidence, given the infection risk scenario, obeying the behavior of the disease COVID-19 in Brazilian territory. Subsequently, technical note no. 12 - COVID-19 infection and risks to women in the pregnancypostpartum cycle ${ }^{(13)}$, in order to expose the available evidence to managers and health professionals and contribute to a better understanding of the risks to pregnant and postpartum women, thus suggesting protective measures and including a flowchart of clinical management of pregnant, parturient, and postpartum women during the pandemic of COVID-19.

It is important that women have trusted support people, including health professionals and caregivers around them, during labor, childbirth, and postpartum ${ }^{(5,11)}$. The ban or restrictions on the presence of companions, doulas and visitors could undermine women's confidence in normal childbirth and negatively affect their experience of pregnancy and childbirth ${ }^{(5,8)}$. When we are able to understand childbirth as a unique and unrepeatable event, we will probably be able to recognize the importance of providing each woman with continuous, conscious and respectful support for them to have a positive childbirth experience, regardless of the clinical course of their labor. Considering that this is an important step not only for the definition of women's health and well-being, but also for their companions and family, whose mental health has been affected ${ }^{(8)}$.

Unlike many situations in the past, information in this crisis has evolved rapidly. As science transmits data, health professionals and civil society demand that health authorities clarify the guidelines. But that cannot neglect the countless studies published before the COVID-19 pandemic, which looked at the associations between obstetric interventions and obstetric, fetal and child outcomes. For example, the risks associated with induction of labor and unnecessary caesarean sections are proven, especially in the short, medium, and long term maternal and child health indicators, as well as in the experience of women giving birth.

Many of these practices have brought to the public some worrying realities, also regarding the rights of pregnant, parturient, and postpartum women, which may be being compromised due to inadequate obstetric protocols. However, even during the pandemic, public health concerns need to be balanced with the need to respect autonomy, informed choice and evidence ${ }^{(7)}$. Not seeking a balance between security of care and respect for women's reproductive rights is a mistake. In this context, we believe it is essential to clarify that the right to autonomy and informed consent have not been revoked. Historically we know that, in times of crisis, the needs of women and children have been highly penalized. Nowadays, it is the duty of health authorities to train women, families, and health professionals with adequate and contextualized information, reducing the uncertainty and inequalities that occur between institutions. Thus, in a life-defining event such as the birth of a child, it is essential to consider the impact of this training on women's health, reproductive rights, and freedom, which can be deeply felt in future societies.

Scheduling of labor inductions and caesarean sections, without clinical reason; prohibition or restriction of the presence of a companion in labor and delivery, without reason; prohibition or restriction of skin-to-skin contact and breastfeeding, without informed consent, regardless of the result to COVID-19, go against the philosophy and basic values of Midwifery Care. Sharing these realities intensifies the way in which the discipline of Obstetrics continues to reject the evidence results. We believe that respect and knowledge of the physiology of labor are the basis for excellent care, in a modern Obstetrics that is sometimes lost between scientific and ethical lapses.

To avoid past mistakes, health professionals have a duty to ensure that women's rights are respected in times of crisis and that health services follow evidence-based practices. The struggles to overcome these basic rights cannot be forgotten. How is it justified to adopt extreme measures without a scientific framework to support them? Why do we make decisions against what is known? When new evidence or data is being rejected, are we talking about the Semmelweiss effect in COVID-19 times? Answers to questions are not easy. We realize that the global uncertainty about the epidemiology of the virus or the very inertia, convenience and resistance to change of some decision makers and also health professionals are supporting controversial clinical practices, that ignore the recommendations of health authorities and that disrespect women's rights in pregnancy and childbirth. In fact, these issues only gave visibility to a problem that has long characterized national and international midwifery services.

\section{Pandemic of the new coronavirus: an unprecedented way to celebrate the International Year of Midwife}

The World Health Organization in a joint effort with the International Confederation of Midwives, the International Council of Nurses, Nursing Now and the United Nations Population Fund stipulated that 2020 would be the International Year of the Nurse 
and the Midwife. With the COVID-19 pandemic, all celebrations and events were cancelled. But, if they aimed to create greater public awareness and appreciation of the service provided to people by these professions, that objective was not suspended. They wanted, in the current circumstances, that the world realized the potential of these professions and how much they have technical-scientific knowledge, responsibility, risks, resistance and selflessness. No celebration or event would achieve such an impact.

In the area of midwifery care, it is essential that, during these challenging and constantly changing times, midwives focus on the duty to assist women and families, while preventing the spread of the SARS-CoV-2 virus. At the center of efforts, safe, sustainable, and coordinated care must be taken that meets the protection needs of women and their newborns. It is important to ensure that responses to COVID-19 do not reproduce or perpetuate unfounded and discriminatory practices, as these further increase the vulnerability of pregnant women.

Considering midwives to be valuable resources, from all countries, means that they also need protection to provide the best care for women and newborns, often in difficult circumstances. In other words, it is essential to guarantee the safety of professionals, with the provision of adequate personal protective equipment. COVID-19 disease has shown us again how the world, more than ever, needs a proactive and robust investment in public health resources and infrastructure. For this reason, we believe that this pandemic represents an opportunity and an urgent call to improve health systems, including for midwives.

In the context of the discussion about the most qualified professionals for women's health care, midwives are the main caregivers and specialists in normal birth. The promotion of normal birth is included in the scope of its autonomous competences. Thus, due to their crucial role during the prenatal period, midwives can facilitate the process of reducing fear of childbirth and/or support the adoption of positive feelings about normal childbirth. Fear of childbirth indicates the need for midwives to intervene with women to help redefine their expectations and levels of confidence in their potential to give birth, improve their knowledge of labor and delivery and train them to take informed decisions, and such strategies must be assumed as a key to promote normal childbirth and improve the quality of women's reproductive health.

Disentangling the rhetoric based on fear of the pandemic, which included the fear of childbirth, is something that midwives seek to overcome alongside women and their families. Fear cannot be more dangerous than the new coronavirus. The important thing is to put fear in its place and allow other emotions to emerge, such as trust, security, and hope.

In the world, many midwives work in their institutions or are involved in community initiatives, individually or collectively. There are countless examples in history that show how times of vulnerability can be a source of competence, creativity, and integration in the face of adverse conditions. In the Spanish fever pandemic, Ms. JL Ackerson, a midwife from the Philadelphia society, used her car to serve as a driver for Fleet Hospital. However, in the COVID-19 era, innovative approaches to pregnancy assistance and antenatal education (individual or group) are being explored, and digital technology is replacing face-to-face meetings.
Thus, according to clinical and scientific experience, we believe that a set of cognitive, behavioral, and emotional strategies is needed to respond to the challenge of fear of childbirth in pregnant women during the COVID-19 pandemic. These strategies will not only help to overcome fear but may also favor an approach to it during pregnancy and until delivery. From the experience working with pregnant, parturient, and postpartum women who have recently given birth, as well as through research on interventions to relieve the fear of childbirth, we believe that the focus of support will be on overcoming, empowering and empowering women for normal childbirth.

For the reasons described above, we built a support tool that can be provided by midwives in face-to-face prenatal care or via online, which we designate as First aid kit for pregnant women afraid of childbirth, in time of pandemic of the new coronavirus (Figure 1).

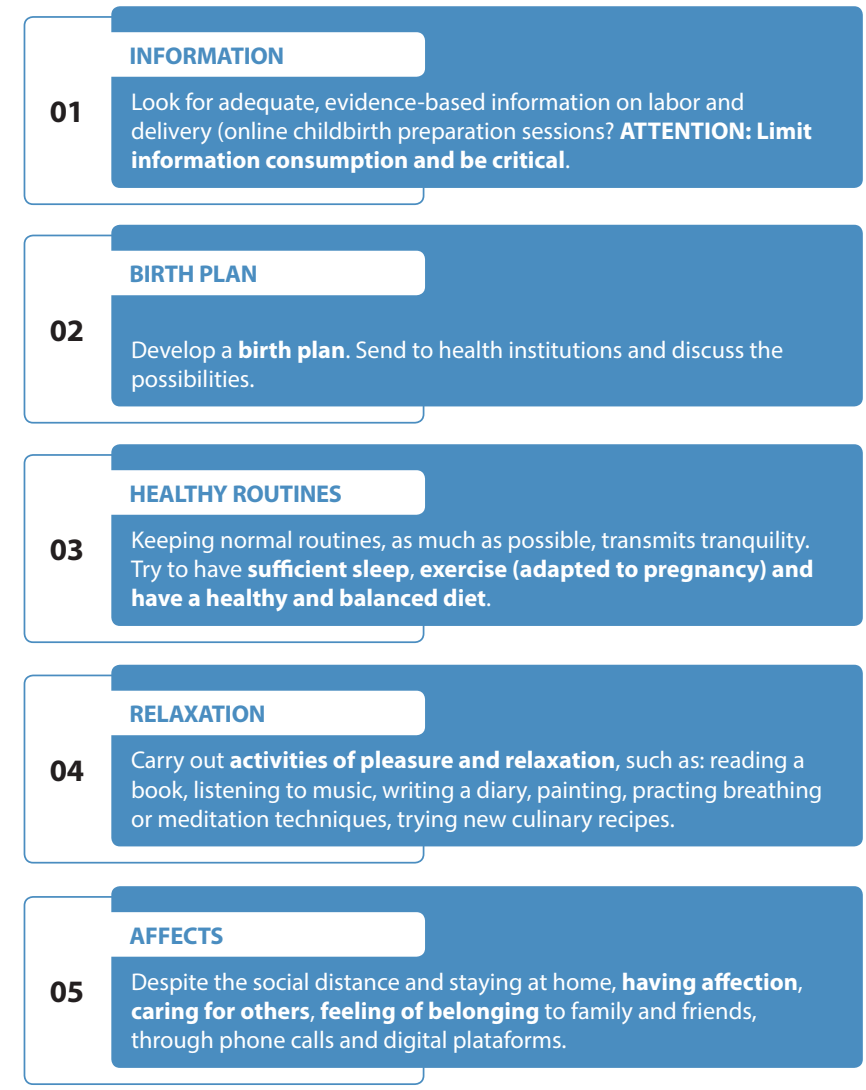

Figure 1 - First aid kit for pregnant women afraid of childbirth, in time of pandemic of the new coronavirus

\section{FINAL CONSIDERATIONS}

The pandemic of the new coronavirus and the protocols implemented by health institutions to prevent the transmission of the SARS-CoV-2 virus have reconfigured the expectations of pregnant women in relation to childbirth, causing additional levels of fear, concern and uncertainty. Further reading on the construct of fear of childbirth, in this period of sanitation crisis, makes us consider a closer correlation of pregnant women with feelings of anguish, helplessness, insecurity and a feeling of isolation and restriction. In fact, we are talking about negative constructions that can have unwanted repercussions on the experience of pregnancy, childbirth, 
postpartum and motherhood itself. Probably, much of the pandemic's impact on the reproductive health and well-being of women and families will not be recognized, because the effects seen will not only be the direct result of infection or prevention, but also the indirect consequences of health systems, due to the pressure from hospital protocols, restrictions on assistance and the redirection of resources.

The current pandemic has brought a chronic problem to everyone: the paternalistic system for the approach to childbirth, which persists in some countries and in some regions within the same country, aggravated by inconclusive scientific data on the behavior of the virus and compliance with measures protection and use of protective equipment. Access to respectful, inclusive and quality health care has proven to be an unequal right when obstetric practices that are not conformed and lack scientific validation of the recommendations on the topic (WHO, MS, DGS, RCOG, ACOG), which has become particularly evident over the past few months. However, in several institutions there are dissonant voices, working based on the evidence and trying to adapt to the circumstances, free from fear and inertia, as is the case of many midwives who want to protect those they care for: women/newborns and family.

Nowadays, many pregnant women and their partners, afraid of childbirth, have made their "voice" reach health professionals, the media and social networks because they are aware of what they feel and their needs in the face of a state of vulnerability, in the form of fears, which limits your experience of pregnancy, childbirth and motherhood. Talking about the fear of childbirth in times of the new coronavirus pandemic means contributing to more positive childbirth experiences for women, according to scientific and ethical obligations. And, when we refer to positive childbirth experiences, we speak much more than mortality/morbidity rates, protocols, and clinical interventions. We speak of satisfaction, sense of accomplishment, mental health, empowerment, quality of life, consent, security, support, information, proximity and integrity, which makes us believe that we address important issues for civil society, health professionals and institutional decision makers and politicians.

May we move from fear to hope.

"This is a time for prudence, not panic. Science, not stigma. Facts, not fear. - United Nations Secretary-General, António Guterres

\section{FUNDING}

This article was supported by National Funds through FCT Fundação para a Ciência e a Tecnologia,I.P., within CINTESIS, R\&D Unit (reference UIDB/4255/2020).

\section{REFERENCES}

1. World Health Organization (WHO). Coronavirus disease (COVID-19) pandemic [Internet]. 2020 [cited 2020 Aug 2]. Available from: https:// www.who.int/emergencies/diseases/novel-coronavirus-2019

2. World Health Organization (WHO). Coronavirus disease (COVID-19): Situation Report - 195 [Internet]. 2020 [cited 2020 Aug 2]. Available from: https://www.who.int/docs/default-source/coronaviruse/situation-reports/20200802-covid-19-sitrep-195.pdf?sfvrsn=5e5da0c5_2

3. Organização Pan-Americana da Saúde (OPAS/OMS). Folha informativa - COVID-19 (doença causada pelo novo coronavírus). [Internet]. 2020 [cited 2020 August 2]. Available from: https://www.paho.org/bra/index.php?option=com_content\&view=article\&id=6101:covid19\&ltem $\mathrm{id}=875$

4. Ministério da Saúde (BR). Coronavírus - COVID-19. [Internet]. 2020 [cited 2020 August 1]. Available from: https://coronavirus.saude.gov.br/.

5. World Health Organization (WHO). Clinical management of COVID-19. [Internet]. 27 May 2020. [cited 2020 July 31]. Available from: https:// apps.who.int/iris/bitstream/handle/10665/332196/WHO-2019-nCoV-clinical-2020.5-eng.pdf?sequence=1\&isAllowed=y

6. Dencker A, Nilsson C, Begley C, Jangsten E, Mollberg M, Patel H, et al. Causes and outcomes in studies of fear of childbirth: a systematic review. Women Birth. 2019;32(2):99-111. doi: 10.1016/j.wombi.2018.07.004

7. Vivilaki VG, Asimaki E. Respectful midwifery care during the COVID-19 pandemic. Eur J Midwifery. 2020;4:1-2. doi: 10.18332/ejm/120070

8. Royal College of Obstetricians and Gynaecologists, Royal College of Midwives, Royal College of Paediatrics and Child Health, Public Health England and Public Health Scotland. Coronavirus (COVID-19) Infection and Pregnancy: Information for healthcare professionals Version 11 [Internet]. 2020. [cited 2020 Aug 2]. Available from: https://www.rcog.org.uk/globalassets/documents/guidelines/2020-07-24coronavirus-covid-19-infection-in-pregnancy.pdf

9. American College of Obstetricians and Gynecologists. Novel Coronavirus 2019 (COVID-19): Practice Advisory [Internet]. 2020 [cited 2020 Aug 2]. Available from: https://www.acog.org/clinical/clinical-guidance/practice-advisory/articles/2020/03/novel-coronavirus-2019

10. Centers for Disease Control and Prevention (US). Coronavirus Disease 2019 (COVID-19): if you are pregnant, breastfeeding, or caring for young children [Internet]. 2020 [cited 2020 Jul 31]. Available from: https://www.cdc.gov/coronavirus/2019-ncov/need-extra-precautions/ pregnancy-breastfeeding.html

11. Direção Geral de Saúde (PT). COVID-19: Fase de Mitigação - Gravidez e Parto. Orientação n 018/2020 (última atualização: 5 de junho de 2020)[Internet]. 2020 [cited 2020 Aug 2]. Available from: https://covid19.min-saude.pt/wp-content/uploads/2020/06/i026356.pdf

12. Ministério da Saúde (BR). Nota Técnica No 9/2020-COSMU/CGCIVI/DAPES/SAPS/MS. Recomendações para o trabalho de parto, parto e puerpério durante a pandemia da covid-19. [Internet]. 2020 [cited 2020 Jul 31]. Available from: https://portaldeboaspraticas.iff.fiocruz.br/ wp-content/uploads/2020/04/SEl_MS-0014382931-Nota-Tecnica_9.4.2020_parto.pdf

13. Ministério da Saúde (BR). Nota Técnica No 12/2020-COSMU/CGCIVI/DAPES/SAPS/MS. Infecção COVID-19 e os riscos às mulheres no ciclo gravídico-puerperal[Internet]. 2020 [cited 2020 Jul 31]. Available from: https://central3.to.gov.br/arquivo/505116/ 